Украӥнська мова

Ukrainian language
ISSN: 2411-6181(on-line); ISSN: 2311-9896 (print)

Current issues of social studies and history of medicine. Joint UkrainianRomanian scientific journal, 2017, №:4(16), P. 10-13

UDK 378.096:615(09)

DOI 10.24061/2411-6181.4.2017.118

ОБРЯДОВИЙ ДИСКУРС ПРО РІЗДВЯНІ РОЗВАГИ

У БУКОВИНСЬКИХ ГОВІРКАХ: ЕТНОКУЛЬТУРНИЙ

ТА ЛІНГВІСТИЧНИЙ АСПЕКТИ

Наталія РУСНАК,

Чернівецький національний університет

імені Юрія Федьковича Чернівці (Україна)

n.rusnak23@rambler.ru

Юлія РУСНАК,

ВДНЗ України «Буковинський державний

медичний університет», Чернівці (Україна)

julijarusnak@rambler.ru

\title{
RITUAL DISCOURSE ABOUT CHRISTMAS ENTERTAINMENTS \\ IN BUKOVINIAN DIALECTS: ETHNOCULTURAL AND \\ LINGUISTIC ASPECTS \\ Natalia RUSNAK,
}

Chernivtsi National University named after Yuriy Fedkovich.

Chernivtsi (Ukraine)

Yulia RUSNAK,

Higher State Educational Establishment of Ukraine

«Bukovinian State Medical University» Chernivtsi (Ukraine)

Researcher ID: S-8544-2016 ORCID 0000-0001-9941-4411

Руснак Н., Руснак Ю. Обрядовый дискурс о рождественских забавах в буковинских говорах: этнокультурный и лингвистический аспекты. Цель статьи - выяснить этнокультурную и лингвистическую специфику диалектного дискурса о рождественских развлечения в буковинских говорах, описать реликты архаического (мифологического) мышления нации. В статье использованы описательный, структурный, сравнительно-типологический методы исследования, а также метод моделирования. С помощью описательного метода обобщены наблюдения над фактическим материалом, структурный метод позволил инвентаризировать и систематизировать языковые явления, сравнительно-типологический - подчеркнуть специфику языковых явлений. Прием моделирования привлечен для анализа структуры ДТ. Научная новизна. Впервые в украинском языкознании осуществлен системный анализ диалектного дискурса о рождественских развлечениях на материале буковинских говоров, выяснено лингвальное проявление этнокультурной специфики ДТ. Выводы. В диалектном дискурсе о Рождестве воспроизведены развлечения светского характера (танцы) и религиозно-светского (колядование). Етнокультурную специфику ДТ буковинских говоров подчеркивают культурные термины, среди которых немало локальных культурных понятий - неразложимых словосочетаний.

Ключевые слова: диалект, диалектный текст, дискурс, культурный термин, интертекстуальность, сравнение, речевое климе.

Постановка проблеми та її зв'язок з важливими науковими завданнями. Дискурс - один 3 актуальних, загальнонаукових термінів, однак використовується переважно у працях філософів та філологів. Дискурс (від фр. мовлення, з лат. - блукати, розгалуження) - зв'язний текст у контексті численних супровідних фонових чинників; текст, занурений у життя ${ }^{1}$.

В. Чернявська пропонує два визначення дискурсу, в яких враховано, по-перше, залежність тексту від комунікативної ситуації, по-друге, узагальненість і конкретність тексту. Пор.: Дискурс1 позначає конкретну комунікативну подію, яку фіксують у письмових текстах і усному мовленні, здійснюють у певному когнітивно та типологічно обумовленому комунікативному просторі ${ }^{2}$. Дискурс розуміють як сукупність тематично співвіднесених текстів: тексти, які об'єднують у дискурс, звернені до однієї загальної теми. Зміст (тема) дискурсу розкривається не одним окремим текстом, але інтертекстуально, у комплексній взаємодії багатьох окремих текстів $^{3}$. Усі діалектні тексти (далі ДТ) буковинських гові- рок про Різдво розглядаємо як обрядовий діалектний дискурс, вужче - діалектний дискурс про різдвяні розваги.

Різдвяний цикл реалізує архаїчну свідомість, яка має романтичний, поетичний характер і для якої час не неперервний, а циклічний, повторюваний, сакральний. Сучасна людина існує в лінійному, неповторному часі історичному, або профанному. На думку М.Еліаде, людина долає профанний час завдяки ритуалам, релігії, читанню, театру ${ }^{4}$.

Відомо, що релігійні свята становлять симбіоз народного та священного світосприйняття. Народно-поетичну основу Різдвяного циклу яскраво відтворюють забави.

Матеріалом дослідження послугували розповіді буковинських діалектоносіїв - ДТ про Різдвяний цикл, цінні лінгвальною та культурною інформацією.

Аналіз останніх досліджень і публікацій, у яких започатковано розв'язання проблеми. У діалектології текст перебуває в полі зору багатьох дослідників (П. Гриценко, Л. Касаткін, В. Гольдін, Н. Гуйванюк,

\footnotetext{
${ }^{1}$ Selivanova O. Suchasna lingvistyka: terminologichna entsyklopediya [Modern linguistics: terminology encyclopedia], Poltava: Dovkillya-K., 2006, P. 119.

${ }^{2}$ Chernyavskaya V.E. Lingvistika teksta: Polikodovost', intertekstual'nost', interdiskursivnost' [Linguistics of the text: Polycodicity, intertextuality, interdiscursivity], M., Librokom, 2009, P. 143.

${ }^{3}$ Ibid., P. 144.

${ }^{4}$ Eliade M. Sv'ashennoye i mirskoye [Sacred and mundane], M., Izd-vo Mosk. Un-ta, 1994 - 144 p.
} 
М. Делюсто, Н. Руснак, Н. Ястремська). Так, П. Гриценко зазначає: „Діалектні тексти репрезентують реальне буття мови, склад, функції мовних одиниць, динаміку їх форми і змісту; це реальність мови, не затиснена і не трансформована вузькими берегами нормативних приписів і обмежень, як у літературному різновиді мови. Свобода мовної самореалізації діалектоносія дозволяє співіснувати на паритетних засадах архаїчних та інноваційних, питомих i засвоєних елементів, узуальних для системи говірки і функціонально обмежених одиниць"

Мета статті - з'ясувати етнокультурну та лінгвістичну специфіку діалектного дискурсу про різдвяні розваги у буковинських говірках, описати релікти архаїчного (міфологічного) мовомислення нації. Наукова новизна. Уперше в українському мовознавстві здійснено системний аналіз діалектного дискурсу про різдвяні розваги на матеріалі буковинських говірках, 3'ясовано лінгвальний вияв етнокультурної специфіки ДТ.

Методи дослідження. Методологічну основу статті становлять твердження про мову як спосіб відтворення дійсності, мову як системне явище, про нерозривну єдність мови і мислення, взаємозв'язок абстрактного і конкретного, суб'єктивного й об'єктивного в мові, співвідношення форми і змісту мовних одиниць. У ній застосовано мультидисциплінарний підхід до вивчення мовних явищ. Як основні використані описовий, структурний, зіставнотипологічний методи дослідження, а також метод моделювання. За допомогою описового методу узагальнено спостереження над фактичним матеріалом, структурний метод дав змогу інвентаризувати та систематизувати мовні явища, зіставно-типологічний - увиразнити специфіку мовних явищ. Прийом моделювання залучено для аналізу структури ДТ. Як додаткові використано елементи трасформаційного, компонентного та дистрибутивного аналізу.

Виклад основного матеріалу дослідження. Усі діалектоносії говорять про очікування Різдва. У цьому очікуванні вбачаємо дві основи: одна підсвідома, пов'язана $з$ міфологічним мисленням, згідно з яким час - сакральний, священний, міфологічний; він циклічний, повторюваний. Велика роль відводиться символам, ритуалам, які повертають його, робилять зворотним. Повернення часу підтримує природа. У ДТ, звичайно, вербалізована друга зовнішня, свідома, причина, пов'язана 3 кінцем посту та забавами:

A та'ко йак ууже ч'і'кали шо 'майе бути Св'і'тий 'веч'ір / так ч'і'кали / ма'л'i 'дужи ч'i'кали // 'мама нава'рит йі'ди / на С 'і'тий 'вечір/ $і$ ми так ў'кусно пойі'мо// х'лопи’і йдут кол'іду'вати // ви'лик'i х'лопи’ $і$ йдут до д'iў'чат / кол'іду'вати// йдуm по ха'max // д'iy̆'чата би'рут до 'хати / прий'майут / х'лопи' $і$ кол 'i'дуйут // ну / пор'іў'н'ати / то теж 'було 'весило / а тим ча'сом 'тожи 'було 'весило // (с. Михальча Сторожинецького рну).

„Різдвяні забави” у діалектному дискурсі про Різдво представлено розвагами світського характеру (танці) та релігійно-світського (колядування).

У буковинських говірках побутує система культурних термінів зі значенням „розпочинати танці, бути запрошеною першою”, які наразі перебувають у пасивному складі: розвис'ти 'дании, вис'ти пи'рет, да'вати 'сабаи.

На Буковині не кажуть запрошувати до танцю, а брати гу'л'ати:
А по'тому і'дут уоже на 'даниц // $і$ кот'рий х'лопии, прихо'диў до 'д'іўчини/ вже йі'йі уюсе там брай гу'л'ати / на дан'це // 'тожи 'було 'весило // (с. Михальча Сторожинецького р-ну).

Під час різдвяних свят застосовувалися своєрідні відзнаки для дівчат. Розпочинати танці, або бути запрошеною першою до танцю, - було честю для дівчини. Така честь виказувалася за певні вчинки, наприклад, за те, що дівчата прикрашали хрест на свято Водохреща: то во'ни йіх вили'чайут за то / шо во'ни хрест 'файно угб'рали//(с. Митків Заставнівського р-ну).

Зі значенням ,,розпочинати танці” у буковинських говірках функціонує словосполучення вис'ти пи'рет. Характерно, що культурний термін вис'ти пи'рет вступає у синтагматичні зв'язки $з$ особовим займенником у формі Д.в. ми'н 'i пи'рет х'лопи' $i$ ви'ли, тобто мене запрошували, але ка'вал 'ер пи'ред ви'де, при предикаті вис'ти пи'рет суб'єктом виступає він (хлопець), за зразком він запрошуї ї̈ однак йа n'iш'ла пири'діў (була першою):

Г'iў'чата там кру'гом / m'i шо уби'рали / то во'ни йіх вили'чайут за то / шо во'ни хрест 'файно убб'рали // 'n 'іс'л'а об 'i'да 'даниц / $i$ к'i г'іўччата / кот'p'i хрест уби'рали / тих х'лопи'і 'перид би'рут / к'личут упи'ред у 'даниц // то 'кажут ви'де пи'рет // так йак йа о'ден р'ік уби'рала / ми'н'i пи'рет х'лопи'і ви'ли // $i$ усс'о к'ін'ч'айіси // (с. Митків Заставнівського р-ну); $A$ д'ругий ден' на дан'ции ўже / ией х'лопии / ка'вал'ер пи'ред ви'де // 'перша уั 'даниц і'де // заг'райут музи'канти / н'іх'то ни йде / 'пок'iў/ ни 'n'іде цей шо зака'заў // би'ре иу 'д’іучини // 'к'іл'ко йа п'іш'ла пири'д'іў / шо / ого го// $i$ так // $i$ д'ругого 'вечера ужже ни 'ход'а кол 'iду'вати / лиш т'i / с 'церкви // с 'церкви кол'i'дуйут / б'раитвво / зби'райут г'рош'i на 'церкву // (с. Митків Заставнівського р-ну).

У деяких селах розпочинали танці ті дівчата, які давали більше грошей за коляду. У говірці с. Кам'янка Глибоцького р-ну розпочинати танці - да'вати 'сабаш.

A д’ругойі д'нини / на Р'ізд'во п'разник ви'ликий / у 'церкв'i 'файно в 'ітпрау'йейут // а 'дома р'іх'туйут / уже вс'о по 'іншому / с'коромно // хто шо майе ско'ромне // а у'веч'ip/ паруп'ки зби'райуи:и// 'робйа кол'а'ти / пириби'райуц:и за 'д’іда / 'бабу // ци'ганку / шо хто 'хоче // тай 'ход'a по д'іў'ках // ко'л'а'су та'ку 'робйа // тай 'ход'а по д'іў'ках // д’й'ки вже в 'і'нос'а йім г'рошей шо / кол'а'дуйут // а пу'тому 'робйа 'дани'і / $і$ m 'i д’іў'ки шо 'в'інисли 'б'іл'те г'роший / тим да'йут 'сабаш // шан'дар' / пириби'райуц:и за шанда'р'а // шан'дар' тим ко'мандуйе угс'ім // г'рош'і зби'райе // пла'm'а 'музику уже // ск'рипникам // ўже 'к'іл'ко г'роший 'майут // (с. Кам'янка Глибоцького р-ну).

Світські забави Різдвяного циклу, відображаючи архаїчне (міфологічне) мовомислння, грунтуються на народних традиціях. Т.Галіп залишив опис святкування в його родині „старого” нового року - плясу. „В селі Брідку, де був панотцем мій покійний батько. Одного разу на новий рік прийшло церковне братство в гостину. Ми всі посідали до столу. I пішла розмова про святочні обряди, аж тут встали два нвйпорядніші господарі сказали, що хотять вивести старовинний „пляс”. Обнялися за шию i, приспівуючи на якийсь давній лад, зачали пританцьовувати на місці та все на три кроки підбігати вперед, та знов відбігали, легко вклоняючись. Зміст пісні - це було якесь урочисте вітання. Очевидно, цей

\footnotetext{
${ }^{5}$ Grutsenko P. Teksty yak dzherelo doslidzhennya ukrayins'kych govirok Rumuniyi: [peredm.], Pavlyuk M., Robchuk I. Ukrayins'ki govory Rumuniyi: dialektni teksty [Text as a source of Ukrainian dialects research in Romania [introduction], Pavlyuk M., Robchuk I. Ukrainian dialects of Romania: dialect texts], Canada, 2003, P. I-XVI. 
„пляс" міг бути останком релігійних танців 3 поганських часів" $"$. За Етимологічним словником М. Фасмера, слово плясати відоме усім слов'янським мовам, має слов'янське коріння, зі значенням „танцювати, веселитися, радіти, торжествувати"7.

Софія Георгіївна Руснак, діалектоносій 1923 р.н c. Митків Заставнівського р-ну, розповіла про обряд пл'а'сати 'd'iy̌ку, який мав на меті звеличити, відзначити дівчину. Назвою обряду послугувала вербальна частина, яка супроводжує акціональну, учасники дійства приспівують: ой пл'а'ши / пл'а'ши/ ти / кал'і'иуни // mу'б’i д’ій'чина $\tau^{\prime}$ рейцара в'суне. Хлопця жартома названо кал'і'иун. Номінацію кал'і'иун на позначення юнака сприймаємо як вияв ідеї „приниження”, характерної для народної свідомості, яка, за уявою діалектоносіїв, $є$ своєрідним запобіжним заходом від зурочення.

Мовець детально описує обряд, виокремлюючи всіх дійових осіб цього дійства: музиканти, дівчина, хлопці та їх дії. До ритуалу залучено гроші, що засвідчує чинник „нашарування часу”: $\iota^{\prime}$ рейцар - фонетичний варіант слова крейцер ,„розмінної монети із срібла і міді в Німеччині та Австро-Угорщині (XV - XIX ст.)", назва запозичена 3 нім. мови, пов'язана 3 лат. хрест, оскільки на монеті був зображений хрест ${ }^{8}$. За змістом вербальної частини обряду Ой пл'а'ши / пл'а'ши / ти / кал'і'иуни // mу'б'i д’іў'чина т'рейиара в'суне, дівчина повинна була платити юнакові за ії звеличення. Однак, насправді хлопець кидав дівчині гроші, намагаючись у такий спосіб „підкупити” іiі, можливо, показати свою заможність. В основі ритуалу - танцювальні рухи. Семіотичною одиницею виступає соматична система, система танцю, яка і $є$ носієм певної інформації - показує прихильне ставлення до дівчини. У вербальному відтворенні засобів соматичної комунікації, у ДТ, беруть участь лексеми, що відтворюють танцювальні рухи: во'ни сn'л'асуйут// mpon / mpon / mpon / mpon; а во'ни m'ponaйуm / с тропа'ком в'ід 'т'іуччини $і$ на'зад / до 'т'іуччини $i$ на'зат/ так / е зо д'ванаи'ік' рас так; о'ден дан'иуйе; д'ругий подан'иуйе. Танцювальний рух, названий дієсловом $c n^{\prime} л ' a c y$ вати, пояснює звуконаслідувальне слово mpon, від якого твориться словотвірний ланцюг mpon- m'ponamu тро'пак. Пор.:

А вже йак 'д'іуччнна 'майе х'лопиа та'кого / шо стр 'і'чайіси з ним / зди'байіси з ним // то // в'ін би'ре до 'себи од'ного то'вариша $і$ i'dут до 'хати // n'рос'аси до 'хати // i би'рут музи'кант'іу //а к'i йдут биз музи'кан-

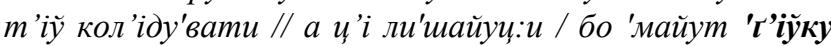
пл'а'сати // d’іуччина с'і'дайе на 'лаўку / би'ре та'p'iл'чик / наси'пайе // за Ри'мун'ійі 'були са'м'i зе'л'ізн'i / з'найіш / г'рош'i / наси'пайе ў та'p'iл'/ $i$ так по'дзуркуйе // 'музика г'райе/ $і$ во'ни сп'л'асуйут // троп / mpon/ mpon / mpon / a к'i // a m'i ш'е музи'канти сп'i'вайут шо // ой пл'а'ши/ пл'а'ши / ти / кал'і'иуни // ту'б'i д'іў'чина т'рейщара в'суне // а во'ни т'ропайут / с тропа'ком в'ід 'г'іуччини і на'зад / до 'т'іуччини і на'зат/ так / e зо д'ванаи, $і к '$ рас так // по'том йак пов'ік'i'дайут ус'і / // бо йа 'майу лиш т'рошки ту'то / г'роший / а во'ни все п'ітки'дайут все ми'н'i / n'ітки'дайут все ми'н'i / а вже йак ни 'майут н'і'чо // то'ди музи'канти г'paйут к'руглойі / о'ден дан'иуйе / той с'і'дайе / би'ре 'д’уучину / д'ругий подан'иуйе // то'ди за ск'iў $i$ / прий'майуи:и // пов 'i'ч'ер'али / то'ди йдут наздога'н'ати кол'ідни'к'іу // $і$ так / та'ко си'лом / а йак ни 'майе 'д'іуучина х'лопияа / тай н'іх'то ни интери'суйіси 'шоби n'i'mu до 'хати/ а то 'гонор буў // (с. Митків Заставнівського р-ну).

Організатором танців, колядування був 'калфа. Простежуємо зв'язок буковинського культурного терміна калфа зі словом румунської мови, де воно мало значення ,Помічник майстра”. Слова в українській та румунській мові мають різні значення, однак семантичний зв'язок між ними існує. Пор.: calfặ, с.ж., подмастерье' .

'Пот’ім прихход'а / кол'адни'ки / ма'л’i / в'с'ак'i / 'd’іти ма'лен'к'i / а 'пот'ім уоже ви'ч'ер'а к'ін'чайіси / при'ход'а ви'лик'i // х'лопи'i в кол'а'ду до д’іў'чат // кал'фи // ну і там вже d'iў'чата в 'i'нос'а / г'pow'i май к'pynн'i// ну i соб'i'paйе m'i г'рош'i / 'тания'i 'робйа // 'пот'ім c'ход’аси / ну вже там в 'ідм 'i'чайут / ден' на той 'танеи // тан'иуйут два дн'i на кол'а'ду // (с. Бобівці Сторожинецького р-ну); Х'лопи'і зби'райуuу:и на 'хак'i / i росприт'і'л'ейут хто й'кими 'буди хо'дити вули'цами // маланку'вати // 'серид них йе о'ден с'тариий // 'калфа // йкий уус'ім ки'руйе // (с.Веренчанка Заставнівського р-ну).

Найголовнішою різдвяною забавою світськорелігійного характеру було колядування, оскільки відповідало духу (призначенню) Різдва - вшановуванню народження Сина Божого. Слово кол'атка та похідні від нього у буковинських говірках вирізняе частотність вживання; вони функціонують 3 тими ж значеннями, що і в літературній мові. Проте у буковинських говірках слово кол'атка набуває нових значень і посилюює свій словотвірний потенціал. Напр.:

Тай кол'ідни'ки ни йтли // у нас кол'ідни'ки ни йшли на Св'а'тий 'веч'ір // іш'ли аж / на Р'ізд'во // на P'ізд'во 'д'іти дн'ом / кол 'іду'вали / а к'i з'росл'і х'лопи'i по д’іууччатах хо'дили уувеч'ір / кол'іду'вали // (с. Митків Заставнівського р-ну).

У говірках слово кол'а'да те саме, що колядувати. Однак воно може використовуватися зі значенням „часовий проміжок, коли колядують": при'ход'a в кол'а'ду, про що свідчить синтагматичний зв'язок: дієслово + в 3.в., за зразком приходять в обід, у день народження, у свято тощо. Пор.:

При'ход’a ви'лик'i // х'лопи’ в кол'а'ду до d’'̌у'чат // (с. Бобівці Сторожинецького р-ну).

У деяких говірках функціонуе слово кол'а' (відзначаємо зміну фонетичного вияву слова) зі значенням „група людей (переодягнених), які ходили колядувати, те саме, що колядники". Слово кол'а'та входить до культурного терміна ро'бити кол'а'九и - у колядуванні беруть участь групи переодягнених носіїв говірок:

У'веч'iр/ паруп'ки зби'райуи:и // 'робйа кол'а'ти / пириби'райуи::и за 'д’іда/ 'бабу // ич'ганку / шо хто 'хоче // тай 'ход'а по д'іў'ках // ко'л'а'ту та'ку 'робйа// тай 'ход'a по д'iў'ках // (с. Кам'янка Глибоцького р-ну). Слово кол'атки може позначати процес колядування, те саме, що колядувати:

С'ат'куйут Р'ізд'во 'першойі д'нини / ко'л'атки /

\footnotetext{
${ }^{6}$ Galip T. Z moyih spogadiv. [From my memories]. Bukovyns 'kuy jurnal [Bukovinian journal],1994, №1-2, P. 171.

${ }^{7}$ Fasmer M. Etimologicheskiy slovar' russkogo yazyka: v 4 t. [Etymological dictionary of the Russian language: in 4 vol.], M., Progress, Vol. 3, P. 291.

${ }^{8}$ Etymologichnyi slovnyk ukrayins'koyi movy [Etymological Dictionary of Ukrainian Language], K., Nauk. dumka, 1982, 2012, Vol. III, P. 82 .

${ }^{9}$ Rumuns'ko-rosiys'kyi slovnyk [Romanian-Russian Dictionary], Bacău, 2008, P.54
} 
// m'ретойі д'нини ўже / Шти'фанийа / цее вже кол'а'ди ни'ма т'ретий ден' на Р'ізд'во // бо вже / бо то лиш два дни кол'а'да йде // вод'нойі д'нини і д'ругойі д'нини / a там ужже Штифа'на // а в'і'так 'дал'ше зноў три дни / 'межи тим 'також // а в'і'так зноў при'ходе C'а'тий 'вечир // o'n'am' C'a'mий 'вечир// зноў так го'туйім / йак на 'перший C'а'тий 'вечир / $і$ в'і'ч'ер'айем так // (с. Рідківці Новоселицького р-ну).

Загалом діалектоносії вільніше поводяться з мовними одиницями, а саме: надають їм нових, зазвичай метонімічних, значень, утворюють на їх основі культурні (локальні) терміни.

У деяких населених пунктах Буковини колядування відбувалося у формі театралізованого дійства. У нашому матеріалі $\epsilon$ розповідь про інсценізацію колядки, тобто це третій вияв відомої колядки: перший вияв - безпосереднє виконання колядки (колядують); другий вияв інсценізація колядки, третій вияв - розповідь про інсценізацію. ДТ становить переказ про інсценізацію колядки „Бог предвічний”, відомої біблійної колядки, яка $є$ церковною духовною піснею, а увійшла в народний побут 3 репертуару християнських общин. Театралізоване дійство у с. Кам'янка Глибоцького р-ну має назву ро'бити I' роде: 'Робйе // по 'нашому 'кажут I'роде. До складу культурного терміна, який становить нерозкладне словосполучення, входить дієслово ро'бити, функціонування якого у буковинських говірках характеризує високий ступінь частотності, та Ірод - власна назва царя Іудейського. Зазвичай культурний термін, який у ДТ уводить конструкція покликання, має статус місцевого, або локального культурного поняття.

У ДТ переплітаються три лінії: а) розповідь про сценку (виділено жирним курсивом); б) ремарки; переказ сценічних дій і зауважень автора, тобто того, що відноситься до пояснення театральних дій (виділено курсивом) і в) відтворення реплік дійових осіб сценки, які передають пряма мова та переповідні конструкції. Розповідь діалектоносія (лінія $а$ ) починає інтродукція теми розповіді; у середині ДТ міститься аксіологічна оцінка дійства, а у кінці (як підсумок) мовець пропонує деякі пояснення цієї ситуації та її логічного продовження. Ремарки (лінія б) відповідають жанру сценарію: короткі речення, односкладні та двоскладні, зазвичай правильно побудовані. Зміст реплік персонажів (лінія б) відтворює зміст колядки, проте мовленню героїв притаманні усі ознаки спонтанності - повтори, синтаксичне невпорядкування, подрібненість на фрагменти (синтагми); воно оформлено у відповідності до фонетико-граматичних закономірностей говірки (із збереженням архаїчних морфологічних рис, наприклад, складена форма майбутнього часу 3 допоміжним дієсловом й'мати, яка нечасто трапляється у діалектному мовленні: йак 'мете йти на'зад, и’ i ме 'мати хист u’'i I'род. У переказі колядки використано міфоніми, на позначення нечистої сили вжито низку синонімів: поган', бисти'на, безбожний Ірод, які мають прозору етимологію; пор.:

'Робйе // по 'нашому 'кажут I'роде // то о'ден I'род $i$ три ияа'p'i // то// та'ка с'ценка// ууни су'б'i гу'вор'а // то прий'майут до 'хати йіх // кла'дут три/ ш'тири ст' 'іл'ции // i I'род насири'дин'i m'i три / ш'тири май по'зад’ $i$ // $i$ вни nu'maйуm / I'poд пи'тайе / ку'да ўни йдут // вни 'кажст // ми йдем ў В'іфл'і'йем / поже'лайем спо'койем і по'вернемс'а // $a$ I'poд йix n'poce / шо йак 'мете йти на'зад // ви повер'н'іт // шоб і йа п'і'шоў покло'нитиси йак 'Богови св'і'тому // a'ле йім си пока'заў вно'чи 'ангел' / $i$ ска'заў 'инший пут'/ 'шоби вни повер'нули// 'шоби ни повер'тали до І'рода / бо І'род 'хоче в'бити / I'суса Хрис'та // i це вс'о с'ценка та'ка // 'дужи 'файна // $\boldsymbol{i}$ 'музику/i ан'zел'а // I'род пи'тайіси / прик'ликали ан'гел'а // 'ангел' йо'му 'кажи // кот'рий // в 'ін nи'тайе // ц’i ме 'мати хист ц'і І'род / ц’і І'сус Хрис'тос ц’i 'майе воро'г'іў // а той ска'зау / шо 'майе воро'г'іў // хто?// 'перший ти // I'род 'в 'ізнаў 'ангел' а // 'шоби ни ка'заў 'дал'i // $\boldsymbol{i}$ то йім пла'тили за то / д'іў'ки // та і ни лиш д'їй'ки // хто хо'm'iў зап'рос'уваў йіх до 'хати тай во'ни / иу с'ценку / г'рали // а ууже пу'тому // хо'дили кол'а'ти // ни ста'вало 'ночи / ш'е й дн'ом хо'дили // кол'іду'вали// ў'с'екойі кол'idy'вали // (с. Кам'янка Глибоцького р-ну).

Далі діалектоносій відтворює колядку, зберігаючи фонетико-граматичні особливості говірки:

Бох прид'в'ічний народиў'с'а // з'іймиоу днес' iз ни'бес 'шоби спас л'уд св 'ій ўвес і ў'm 'ішиусс'а //

у В 'іфл'і'йем'i наро'оиусс'а // мис'і'йа / Хрис'тос наш і пан наш дл'а вс 'ix нас // нам народиўсс'а //

там три 'цар'i i'dут з да'ром до В'ірл'i'йем м'iс'та / де При'чиста 'Д'іва 'сина наро'дила //

ви три 'цар 'i / ку'да йде'те // ми і'дем у В 'іфл 'i'йем / жела'йім споко'йім / i по'вернимс'а //

увис'тиусси 'ангел' 'божий / сампи'рет пасто'р'ам / а по'тим зв 'ізда'р'ам $і$ земс'к'ім ияа'р'ам //

'иншим 'пут'ом повир'нули // пога'ну / бисти'ну / безбож'ного Іро'ду 'зоусс'ім мину'ли // (с. Кам'янка Глибоцького р-ну).

Святкування Різдва передбачає особливі вітання. На Буковині віншування має усталену форму, становить обрядове кліше: традиційні побажання щастя-здоров'я, довгих років життя набувають діалектного фонетичного вияву. До складу традиційного віншування входить церковнослов'янський фразеологізм м'нога л’im. Фразеологізм „обігрується”: м'нога л’іт / до ста л'іт // 'пока пан 'Бох призна'чиу вам в 'ік. Дві загальнолюдські цінності - щастя, здоров'я - у народній свідомості існують в єдності, на мовному рівні творять складне слово ' $w$ 'ic'm'a здо'ровл'a. Усталеною віншувальною конструкцією діалектного характеру є йік у 'и'іс'т'i здо'ров 'i доч 'i'кали / так у 'и'іс'm 'i / здо'ровл 'і в 'іпро'вадили:

То о'ден чоло'в'ік в 'іншу'вау гос'подар'іў 'дому // ка'заў та'к'i сло'ва // в'ін'шуйу вас 'и'ic'm'iм здо'роўім / с 'цими св'і'тами Р'ізд'в'еними // йік у 'ш'ic'm'i здо'ров'i доч'i'кали / так у 'ш'ic'm'i / здо'ров’і в'іпро'вадили // к'рашчих / виси'л'іших // м'нога

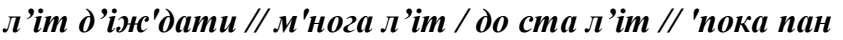
'Бох призна'чиў вам в'ік // гос'подар' 'д'екуваў за в 'іншу'ван'а і пригош'чаў л'у'дий // (с. Лашківка Кіцманського р-ну).

Незважаючи на те, що у віншуванні міститься вказівка на довгі роки життя, обов'язковим його компонентом є зворот доч'i'кати 'нар'ік, який не заперечує побажання довгих років життя, а лише підсвідомо вказує на циклічний зворотний характер часу, тобто прожити цикл - рік, повернутися до тієї ж точки відліку:

Ўс'і гу'л'али / см'і'йелиси / в 'i'тали о'ден 'одного с св'і'тами і ба'жали доч'i'кати 'нар'ік // (с. Лашківка Кіцманського р-ну).

У діалектному дискурсі віншування як обрядове кліше реалізує категорію інтертекстуальності. Обрядове кліше може існувати у варіативній формі. Так, наступний ДТ пропонує варіант попереднього віншування, яке передовсім відрізняє більший обсяг. У ДТ міститься вказівка на

\footnotetext{
${ }^{10}$ Lanovyk M. Ukrains'ka narodna slovesnist' [Ukrainian folk literature], L’viv: Litopys, 2000, P. 129
} 
адресанта-відправника обрядового кліше так йа вам / йак 'ваша ку'ма / су'с'іда / n'рийатил'ка сир'дешно жи'лайу, тобто віншування може бути вкладене в уста будь-якого діалектоносія. Обрядове кліше починає усталена конструкція - привітання, яке виконує фатичну функцію: 'добрий 'веч 'ip вам - формула привітання, ускладнена займенником вам, який відносить конструкцію до визначених осіб. Дієслово віншувати у буковинських говірках реалізує дві семи: ,звертатись до когось 3 певної нагоди” в 'ін'чуйімо св'а'тим Рождист'вом / I'сусом Хрис'том і сему „бажати комусь добра" в'ін'чуйімо вас ш'частим / з'дороуйам. В усталеній синтаксичній конструкції звучить традиційне побажання вічних людських цінностей - щастя, здоров'я: йа'к'істи уу ш'час'm'y / здо'роуйу доч'і'кали / а'бисти у ш'час'm'y / здо'роуйу в 'ітпро'вадили. Клішована конструкція, мета якої акцентувати увагу на ідеї стабільності, на факторі теперішнього часу, факторі точки відліку доч' $i$ 'кали - в'ітпро'вадили. Специфіка синтаксичної конструкції у тому, що обидві іiі частини містять підрядний сполучник, при відсутності головної частини. Місцевого колориту надають діалектні сполучники йа'к'icmu (сполучник умови), а'бисти (сполучник мети) - це архаїчні граматичні явища, які трапляються лише у фольклорних текстах. Ідея довголіття проходить трьома лініями: в 'im сто л'іт до ста л 'іт; 'пок'іуу пан Бог назна'чиу в 'ік; а'бисти доч 'i'кали в 'іт:' тепир за р'ік. У фінальній частині обрядового кліше підкреслений його релігійний характер: $a^{\prime} б и$ вам с 'о'год 'н 'ішн' $i$ n'іс"н 'і і за'бави 'були па'хушчими йак с ка'дила дим / а'би шч'а м'ногайа л'іт про'жили і на 'в'інец йо'го 'царства заслу'жсли / 'бисти си з'іс'тали 'энитил'ами ни'бесного 'paйy. Побажання рясніє лексикою, словосполученнями, які характерні для релігійної сфери використання. Про відтворення готової вербалізованої семіотичної одиниці (опрацьований варіант ДТ) свідчать засоби художньої виразності - порівняння, синтаксичний паралелізм, градація, які створюють стилістичну конвергенцію:

А'би пов'інчу'вати с св'а'тами // при'ход’а $i$ 'кажут // 'добрий 'вечір вам/ з Рождист'вом хрис'товим / він'чуйімо вас с ш'частим / з'дороуйам / св'а'тим Рождист'вом / І'сусом Хрис'том // йа'к'істи у ш'час'm'y / здо'роуйу доч'i'кали / а'бисти у ш'час'm'y / здо'роуйу в'ітпро'вадили / в'іт сто л'іт до ста л'іт / 'пок'іў пан Бог назна'чиў в'ік / а'бисти доч'i'кали в'ім 'тепир за р'ік / а'би вам с'о'год'н'ішн'i n'ic'н'i $\boldsymbol{i}$ за'бави 'були па'хушчими йак с ка'дила дим/ а'би шч'а м'ногайа л'ім про'энили і на 'в'інец йо'го 'царства заслу'жнли / 'бисти си з’іс'тали 'энитил'ами ни'бесного 'райу / так йа вам/ йак 'ваша ку'ма / су'с'іда / п'рийатил'ка сир'дешно жи'лайу // $і$ шо тих за ск'іў / прий'майут/ ўже ско'ромними ст'равами // $i$ иеей 'тазда зби'райіси з 'ними / $i$ 'дал'i $i$ 'дут // так про'вод'а со'б'i // до пирид:'нини 'ход'а // (с. Митків Заставнівського р-ну).

Висновки та перспективи подальших досліджень. У діалектному дискурсі про Різдво відтворено розваги світського характеру (танці) та релігійносвітського (колядування). До загальної панорами календарної обрядовості (обрядового дискурсу) кожен ДТ привносить якусь неповторну рису, промовляючи „голосом” окремої говірки, назагал створюючи „багатоголосся” буковинських говірок. Етнокультурну специфіку ДТ увиразнюють культурні терміни, серед яких чимало локальних культурних понять - нерозкладних словосполучень. Категорію інтертекстуальності реалізують мовленнєві кліше-віншування.

Rusnak N., Rusnak Y. The purpose of the article is to explore the ethnocultural and linguistic specifics of dialectal discourse about Christmas entertainments in Bukovinian dialects, to describe the relics of the archaic (mythological) thinking of the nationality. Descriptive, structural and comparative-typological research methods as main are used in the article, as well as the method of modeling. With the help of a descriptive method the observation over the actual material was generalized, the structural method enabled to invent and systematize language phenomena, comparative-typological - to emphasize the specifics of language phenomena. Method of modeling is involved for the analysis of the dialectal text structure. Scientific novelty. For the first time in Ukrainian linguistics a systematic analysis of the dialectal discourse about Christmas entertainments on the material of the Bukovinian dialects was done, the linguistic form of the ethnocultural specificity of dialectal text was found out.

Conclusions. In the dialectal discourse about Christmas secular nature (dance) and religious-secular (Christmas ritual singing) entertainments were presented. The analysis of dialectal text has testified existence of a large group of cultural terms, among them there are many local cultural concepts, they are special phrases or idioms which can't be divided. The category of intertextuality is found in the speech cliché-gratulation.

Key words: dialect, dialectal text, discourse, cultural term, intertextuality, phonetic dialecticism, speech cliché.

Руснак Наталія - доктор філологічних наук, професор кафедри сучасної української мови Чернівечького начіонального університету імені Юрія Федьковича. Коло наукових інтересів: когнітивна лінгвістика, діалектологія, етнолінгвістика, прагматична текстологія. Автор понад 100 наукових пращь, у тому числі 2 монографій.

Rusnak Natalia - doctor of philological sciences, Professor of the department of Modern Ukrainian Literature Language of Chernivtsi National University named after Uriy Fedcovich. Science interests: cognitive linguistics, dialectology, ethnolinguistics, pragmatic textology. Author of over 100 scientific papers, including 2 monographs.

Руснак Юлія - кандидат філологічних наук, старший викладач кафедри суспільних наук та украӥнознавства ВДНЗ України «Буковинський державний медичний університет». Після захисту кандидатської дисертаиії „Лексика родинних обрядів у буковинському діалекті" за спеиіальністю 10.02.01. - українська мова автор продовжує дослідження у галузі діалектології, етнолінгвістики, викладання украӥнської мови як іноземної. У доробку науковия є 25 публікачії.

Rusnak Yulia - candidate of philological sciences, senior teacher of the Department of Social Sciences and Ukrainian Studies of Higher State Educational Establishment of Ukraine «Bukovinian State Medical University». After defending her dissertation ,The vocabulary of family rituals in Bucovina dialect" in the specialty 10.02.01. - Ukrainian language keeps on researching in the field of dialectology, ethnolinguistics, teaching Ukrainian as a foreign language. In the works of the scientist are 25 publications.

Received: 24.10 .2017

Advance Access Published: November, 2017

(C) N. Rusnak, Yu. Rusnak, 2017 